\title{
DAKWAH PEMBERDAYAAN BERWAWASAN LINGKUNGAN UNTUK DAERAH KONFLIK DI PINGGIRAN HUTAN BALURAN BANYUPUTIH SITUBONDO
}

\author{
Samsul Arifin dan Akhmad Zaini \\ Universitas Ibrahimy Situbondo \\ goessyam99@gmail.com
}

\begin{abstract}
Access to social justice to obtain their rights for the outskirts of the forest in Baluran Situbondo is something difficult. One of them, because of years of conflict. The source of conflict in forest management occurs because of differences between the community and Baluran National Park. These differences, for example due to different perceptions, different knowledge, different values, different interests, and differences in recognition of ownership rights. One offer is the concept of collaborative management, a form of management that accommodates some of the interests of all stakeholders fairly and considers the value of each stakeholder as an equal entity in accordance with the applicable values in order to achieve common goals. The focus of this research is empowering da'wah; namely the propaganda of advocacy, the preaching of economic empowerment, and the propagation of the religious field with environmental insight. Method: using a participatory rural appraisal (PRA) research approach. Results: First, the field of advocacy propaganda; which aims to make the public regain the power of management system, the power of ownership, and the power of unity system that is lost. Second, the mission of economic empowerment is environmentally sound; this program is to improve community welfare and increase community participation in the maintenance of the surrounding environment. Third, the religious field that aims to provide an understanding of environmental fiqh so that the community has a concern about the surrounding environment
\end{abstract}

Keywords: Da'wah, empowerment, environment

\section{Pendahuluan}

Pemberdayaan masyarakat sekitar hutan menjadi salah satu prioritas pemerintahan Jokowi-JK. Pada Rencana Pembangunan Jangka Menengah Nasional (RPJMN) 2009-2014 areal kelola masyarakat sekitar hutan berjumlah 7,9 juta $\mathrm{Ha}$, meningkat menjadi 12,7 juta Ha pada RPJMN 2015-2019. Kebijakan pemberdayaan masyarakat melalui pola kemitraan diatur dalam Permen Kehutanan No. P.39/Menhut-II/2013. Kemitraan ini guna meningkatkan kemampuan dan kemandirian masyarakat setempat untuk mendapatkan manfaat sumberdaya hutan secara 
optimal dan adil $^{1}$.

Pemberdayaan masyarakat sekitar hutan, juga dilakukan di Merak. Merak merupakan sebuah dusun di Desa Sumberanyar Kecamatan Banyuputih Kab. Situbondo. Merak terletak di utara pinggiran hutan Baluran. Pada zaman penjajahan, 1928, Tanah Merak merupakan tanah HGU yang dikelola oleh AH. Loedeboer, orang Belanda. Pada tahun 1974, yang memegang HGU adalah PT. Gunung Kemitir. PT. Gunung Kemitir ini bergerak dalam bidang perkebunan, yaitu pohon turi sebagai pemasok bahan pabrik kertas Basuki Rahmat Banyuwangi. Hanya saja, yang membabat hutan dan mengolah lahan adalah masyarakat. PT Gunung Kemitir tidak membiayai proses pengolahan hutan.

Dalam perjanjiannya, masyarakat wajib menanam tanaman pokok; yaitu pohon turi. Hasilnya, 80\% untuk masyarakat dan 20\% untuk PT Gunung Kemitir. Masyarakat diperbolehkan menanam tumpang sari (semacam lombok) dan hasilnya untuk kebutuhan masyarakat sendiri. Seluruh biaya tanam tersebut ditanggung masyarakat.

Pada kenyataannya, prosentase tersebut juga diberlakukan pada tanaman tumpang sari. Apalagi kemudian pabrik kertas bangkrut. Sehingga kawasan Merak hanya ditanami tanaman tumpangsari. Dengan demikian, selama belasan tahun, masyarakat "diperas" oleh PT. Gunung Kemitir, dengan juga mengambil keuntungan dari tanaman tumpang sari. Pada tahun 1980 Ijin HGU Gunung Kemitir sudah berakhir. Namun PT Gunung Kemitir tetap menarik hasil tanaman kepada masyarakat.

Sekitar tahun 1985, Balai Taman Nasional, secara sepihak menjadikan Merak sebagai bagian kawasan Balai Taman Nasional Baluran. Dalam melakukan aksinya, Taman Nasional melibatkan pihak keamanan untuk mengintimidasi masyarakat. Namun masyarakat menolak. Sebab mereka sudah belasan tahun mengelola tanah tersebut. Lagi pula, kawasan tersebut sebelumnya bukan termasuk daerah Taman Nasional.

Sekitar tahun 1996, Pondok Pesantren Salafiyah Syafi'iyah, melalui pengurusnya, melakukan advokasi dan pendidikan kerakyatan. Namun pertikaian soal lahan antara masyarakat dan TN Baluran masih tetap berlanjut. Masyarakat mengadu ke beberapa pihak, termasuk Jakarta:Kemitraan

Vol. 1 No. 1, April 2019 
DPRD.

Keinginan masyarakat cukup sederhana, mereka berharap agar tetap diijinkan mengelola tanah dan ikut melestarikan hutan. Selama ini, mereka aktif melestarikan hutan Baluran dan satwanya. Mereka menginginkan pola kemitraan dengan TN Baluran. Kata masyarakat, "Kenapa kami yang puluhan tahun menempati daerah ini mau diusir? Kenapa pemerintah hanya mau memelihara binatang? Kalau binatang saja dipelihara, kenapa manusia mau diusir?” Sampai sekarang, status tanah tersebut masih mengambang. Namun secara defacto, pemerintah kabupaten mulai "mengakui" keberadaan mereka. Indikasinya, antara lain: terdapat bangunan SDN, mendapatkan DAK rehabilitasi SDN, dan mendapat bantuan diesel.

Kalau kita telaah lebih jauh, kebijakan perkebunan di Indonesia tidak saja melahirkan dan memperluas kantong-kantong kemiskimam (proverty enclave) dibasis perkebunan namun juga menghilangnya penguasaan dan pemilikan lahan oleh petani karena adanya berbagai bentuk perampasan tanah. Sedangkan kian besarnya angka terhadap petani dalam upaya untuk menyelamatkan aset-aset perkebunan pada era pemerintahan saat ini menunjukkan bahwa politik agraria pemerintah tidak banyak berubah dengan rejim berikutnya. Hak ini membuktikan bahwa meluasnya kemiskinan struktural tidak sekedar sebuah fakta dengan adanya pola sejarah penindasan kolonial yang mempengaruhi relasi struktur sosial ketergantungan terhadap sumber pemiskinan, mempengaruhi tingkat pendidikan petani, buruh, dan masyarakat sekitar perkebunan.

Namun juga diakibatkan tidak adanya kesungguhan dan komitmen pemerintah saat ini (political will) dalam perlindungan petani dan buruh perkebunan. Masyarakat sangat kesulitan memperoleh akses pangan yang layak, pemenuhan hak kesehatan, serta tidak adanya jaminan sosial hidup petani. Penggusuran nilai-nilai kearifan lokal dengan menggantikannya dengan nilai-nilai yang mendorong konsumtifistik-kapitalistik, dari tradisi komunalistik ke individualistic. $^{2}$

Sebagai konsekuensi logis dari kebijakan-kebijakan pemerintah yang tidak populis

2 Boedhy Wijardjo, Assessment Transparansi dan Akuntabilitas Pada Pelakasanaan Pemilu 2004, Sebuah Refleksi Untuk Perbaikan Penyelenggaraan Pemilu, Jakarta: Konsorsium Reformasi Hukum Indonesia (KRHN) bekerja sama dengan Yayasan TIFA, 2008.

$$
\text { Vol. } 1 \text { No. 1, April } 2019
$$


tentang persoalan sengketa tanah perkebunan yang kompleks maka munculah radikalisme petani diberbagai kelompok sektoral dikantong-kantong konflik sengketa tanah perkebunan. Salah satu permasalahan yang kini timbul adalah maraknya perebutan tanah-tanah negara oleh masyarakat atau sering disebut reclaiming (Al Araf, 2002: 77).

Gerakan radikal inilah yang dinamakan reclaiming (reclaiming movement) yaitu, sebuah tindakan perlawanan rakyat tertindas untuk memperoleh hak-haknya seperti tanah, air dan sumberdaya alam serta alat-alat produksi lainnya secara adil demi terciptanya kemakmuran rakyat semesta. Gerakan reclaiming memiliki prinsip anti kekerasan serta menjaga nilai demokrasi dan HAM, sehingga dalam pelaksanaannya tidak menjadikan kaum tani menjadi tirani baru. Oleh sebab itu, gerakan reclaiming lebih mendekati pada proses keyakinan kaum tani atau komonitas kaun tertindas lainnya untuk mengembalikan atau paling tidak memulihkan ketimpangan agraria yang menyebabkan kemelaratan dan kemiskinan di pedesaan (Perdana, 2011).

Menurut Tadjuddin (2000, 39-40) sumber konflik dalam pengelolaan hutan terjadi karena perbedaan. Perbedaan tersebut bisa bersifat mutlak namun ada pula yang berbeda persepsi. Perbedaan tersebut misalnya karena berbeda persepsi, berbeda pengetahuan, berbeda tatanilai, berbeda kepentingan, dan perbedaan akuan hak kepemilikan. Untuk mengatasi konflik tersebut Tadjuddin menawarkan konsep manajemen kolaboratif. Manajemen kolaboratif merupakan suatu bentuk manajemen yang mengakomodasikan beberapa kepentingan seluruh stakeholder secara adil dan memandang harkat setiap stakeholder sebagai entititas yang sederajat sesuai dengan tatanilai yang berlaku dalam rangka mencapai tujuan bersama. ${ }^{3}$

Riset Freitas (2014) manajemen kolaboratif (co-management) sebagai model pendekatan yang menggabungkan pendekatan antara state based dan community based yang saling berkolaborasi. Pendekatan ini sangat baik dengan memanfaatkan potensi masyarakat lokal dan mereka menerima manfaat dengan ikut berpartisipasi dalam menetapkan keputasan dalam mengelola sumber daya alam yang mempengaruhi kesejahteraan mereka. Sedangkan bagi pemerintah menerima manfaat dari berkurangnya kewenangan mereka dan menetapkan hak dan wewenang atas hukum yang setara dan mengalihkan sebagian kewenangan mereka kepada

3 Tadjuddin, Dj. 2000. Manajemen Kolaborasi. Bogor: Pusraka Latin. 
masyarakat. ${ }^{4}$

Dalam pola kemitraan ini, kita jangan sampai terjebak pada istilah dan kurang memberikan partisipasi kepada masyarakat. Putra (2013) yang meneliti pola kemitraan di Desa Wisata Pampang Samarinda menemukan model kemitraan yang diterapkan di daerah tersebut hanya model kemitraan semu dan gabungan subordinatif. Pola kemitraannya hanya didominasi pola yang bersifat bantuan, kurang memberi ruang untuk pengembangan SDM dan minimnya pengorganisasian komunitas.Karena itu harus dirumuskan perbaikan tentang penggiatan investasi swasta, pewadahan agen pembaharu, akademisi, perluasan peran komunitas, pemberian bantuan tabungan dan pinjaman, serta pengaktifan KUD sebagai pemersatu aktivitas.

Dalam konteks Taman Nasional, manajemen kolaboratif ini sangat baik untuk diterapkan. Menurut Anshari, kolaborasi tersebut hendaknya berdasarkan ikatan-ikatan antara stakeholder untuk memecahkan masalah bersama; harus dirumuskan tujuan yang jelas dan mudah dicapai. Bila melibatkan beberapa lembaga, manajemen kolaboratif tersebut harus diformalkan karena pada umumnya pimpinan lembaga membutuhkan legalitas suapaya tidak dianggap melanggar prosedur administrasi. Manajeman kolaboratif tersebut juga diterapkan di Taman Nasional Danau Sentarum. ${ }^{5}$

Adnan, H, dkk, memberikan langkah-langkah kongkrit dalam mendorong kemitraan kehutanan, antara lain: Tahap pertama, melakukan pengkajian situasi untuk memahami kondisi terkinipengelolaan dan penguasaan lahan hutan dengan memperkenalkanalat analisis sejarah penguasaan lahan hutan, pola pengelolaanlahan hutan melalui sketsa lahan dan bentang alam/hutan, sertaanalisis pemangku kepentingan. Bagian ini ditutup denganmelakukan analisis konflik dan potensi konflik.

Kedua, melakukan sosialisasi dan prakondisi membangunkemitraan. Diawali dengan membentuk tim sosialisasi danmembekalinya dengan materi tentang kemitraan kehutanan, pendekatan multipihak dan partisipasi dalam pengelolaan hutan. Tahapan ini ditutup dengan

\footnotetext{
${ }^{4}$ Fretas, JMDC, 2014. Kemitraan Pemerintah dan Masyarakat Lokal dalam Pengelolaan Hutan Mangrove di Pantai Utara Kota Surabaya. Jurnal JKMP. Vol.2 No. 2. September 2014, hlm.147-164

5 Anshari, GZ. 2006. Dapatkah Pengelolaan Kolabortif Menyelematkan Taman Nasional Sentarum? Jakarta: Center for International Forestry Research
} 
mempersiapkan kelembagaan kelompok masyarakat yang akan bermitra.

Ketiga, mendorong proses kesepakatan kemitraan kehutanan. Melakukan bedah kapasitas kewirausahaan, mengembangkan prinsip kemitraan, dan memfasilitasi proses kesepakatan. Tahap keempat, merancang mekanisme pemantauan dan evaluasi partisipatif. ${ }^{6}$

Fokus pengabdian dalam program ini adalah dakwah pemberdayaan masyarakat berwawasan lingkungan yaitu kegiatan dakwah pemberdayaan masyarakat. Terdapat tiga bidang garapan yang menjadi fokus pengabdian kami, antara lain:

Pertama, dalam bidang dakwah advokasi. Tujuan advokasi ini secara umum penguatan masyarakat untuk memperoleh kembali kuasa kelola (power of management system), kuasa milik (power of ownership system), dan kuasa manfaat (power of unility system) yang hilang. Kedua dakwah ekonomi, dalam bidang ini kami lebih menitikberatkan dakwah pemberdayaan ekonomi berwawasan lingkungan. Tujuan program ini untuk menyejahterakan masyarakat dan meningkatkan partisipasi masyarakat pada pemeliharaan lingkungan sekitarnya serta meningkatkan pola kemitraan dengan TN Baluran. Ketiga, bidang keagamaan yang bertujuan untuk memberikan pemahaman tentang fiqh lingkungan sehingga masyarakat memiliki kepedulian tentang lingkungan sekitarnya.

Fokus ini dipilih karena beberapa pertimbangan antara lain:Pertama, terdapat pola kemitraan antara masyarakat dan TN Baluran dalam mengatasi konflik. Kedua, TN Baluran mengembangkan ekowisata. Ketiga, terdapat potensi lokal yang belum dimanfaatkan, yaitu kotoran sapi milik penduduk. Ratusan sapi itu, kalau pagi hari dilepas di hutan. Menjelang senja, digiring dan dikumpulkan ke sebuah tempat terbuka dekat rumah penduduk. Penduduk bergiliran menjaga sapi itu sampai pagi. Kotoran sapinya, sampai sekarang belum dimanfaatkan. Karena itu, kami berencana membantu mereka dengan membuat biogas. Dan ampas biogas digunakan sebagai pupuk organik yang akan membantu masyarakat dalam bidang pertanian.Keempat, biogas tidak merusak lingkungan karena CO2 yang dihasilkan langsung dapat diserap tanaman sehingga emisi yang dihasilkan di atmosfer sangat sedikit. Kalau hal ini diterapkan maka tidak akan mengganggu kawasan hutan Baluran. Kelima, program pembuatan biogas ini dapat mengurangi pencemaran udara, tanah, air, dan biologis.

${ }^{6}$ Adnan, H, dkk. 2015. Meretas Jalan Kemitraan. Jakarta: Kemitraan

$$
\text { Vol. } 1 \text { No. 1, April } 2019
$$




\section{METODE}

Strategi yang dapat digunakan dalam melakukan dakwah pemberdayaan ini adalah dengan menggunakan pendekatan pengabdian masyarakat berbasis Participatory Rural Appraisal (Daniel, 2006: 37-47; Sukardi, 2005: 241-247). Strategi ini diharapkan data problematika masyarakat yang dijelaskan di atas (hasil studi pendahuluan) dapat ditelaah kembali, didalami bersama-sama untuk kemudian direncanakan alternatif problem solvingnya bersama masyarakat. Sehingga dapat menumbuhkan kesadaran bersama karena mereka terlibat di dalamnya, dan tim berperan hanya sebagai fasilitator.

Adapun dalam implementasinya, program ini akan dilakukan melalui beberapa cara atau metode-metode sebagai berikut:

Pertama, pengenalan situasi dan membangun restu masyarakat.Kedua, melakukan pengkajian keadaan wilayah (secara umum dan topikal), yaitu melakukan pengkajian terhadap peta wilayah, keadaan sosial-ekonomi, sosial politik, sosial budaya dan rekonstruksi sejarah masyarakat Merak secara umum. Setelah itu, dilanjutkan dengan melakukan kajian wilayah secara mendalam tentang problem sosial keagamaan masyarakat Merak dengan cara mengkaitkan problematika dan potensi wilayah di daerah tersebut. Ketiga, menyusun rencana aksi secara partisipatif bersama warga,yaitu merancang kegiatan sesuai dengan problem yang ditemukan dari hasil kajian wilayah bersama-sama dengan warga yang didasarkan atas kebutuhan mereka. Keempat, melaksanakan aksi, yaitu melakukan kegiatan atau upaya-upaya untuk memecahkan problem yang telah dikaji bersama-sama dengan warga dan dilakukan bersama-sama dengan warga pula.

Kelima, melakukan evaluasi dan refleksi, yaitu melakukan monitoring dan evaluasi atas upaya-upaya yang telah dilakukan pada aktivitas sebelumnya untuk melihat sejauhmana efekitivias dan efesiensinya. Dan bagaimana melakukan perbaikan ulang (menyusun siklus berikutnya selama masih mungkin)

\section{PEMBAHASAN}

\section{Pengenalan Situasi ke Melaksanakan Aksi}

Dusun Merak termasuk wilayah terpincil dan terpinggirkan. Akses ke daerah tersebut cukup sulit dijangkau. Ada dua cara untuk ke wilayah Merak. Pertama melalui jalan laut dengan 
kendaraan perahu, namun waktunya terjadwal. Sekitar jam enam pagi, masyarakat Merak biasanya belanja atau menjual hasil tanamannya ke pasar Mimbo dengan naik perahu. Sedangkan pulangnya, sekitar jam setengah dua belas siang. Hanya waktu-waktu itulah yang ada perahu ke Dusun Merak. Jarak tempuh perahu antara Merak-Mimbo sekitar dua jam.

Kedua melalui jalan daratan. Jalan daratan ini ditempuh melewati kawasan hutan Baluran. Jalannya belum teraspal dan masih alami, penuh bebatuan dan tanah liat. Kalau hujan, jangan coba-coba melewati jalan darat ini. Karena jalan darat tidak bisa dilewati, sepeda tidak akan bisa berjalan karena penuh dengan tanah.

Dusun Merak yang terletak di pinggiran Hutan Baluran termasuk daerah binaan kami. Kami sering mengadakan kegiatan pengabdian masyarakat. Misalnya pada saat Kuliah Kerja Nyata (KKN), "Lintas Dakwah “ (kegiatan pengabdian masyarakat yang dilaksanakan Fakultas Dakwah), dan beberapa kegiatan pengabdian masyarakat lainnya. Kami sudah saling mengenal dengan masyarakat Dusun Merak. Sehingga pada tahapan ini kami lebih memantapkan.

Pada tahapan ini, kami mengadakan silaturrahim kepada beberapa masyarakat. Kami mengutarakan maksud dan tujuan kami. Alhamdulillah mereka merespon dan menyambut baik maksud dan kehadiran kami.

\section{Kajian Keadaan Wilayah (secara umum dan topikal).}

Pada tahapan ini tim melakukan pengkajian terhadap peta wilayah, keadaan sosialekonomi, sosial politik, sosial budaya dan rekonstruksi sejarah masyarakat Merak secara umum. Setelah itu, dilanjutkan dengan melakukan kajian wilayah secara mendalam tentang problem sosial keagamaan masyarakat Merak dengan cara mengkaitkan problematika dan potensi wilayah di daerah tersebut.

Tim mencoba memetakan potensi-potensi yang ada dalam Dusun Merak Desa Sumberwaru Kecamatan Banyuputih Kabupaten Situbondo. Mapping ini dilakukan untuk mengenal seluruh posisi atau letak dari rumah penduduk, masjid, lembaga pendidikan, persawahan, ladang, kandang sapi dan lain-lain. Mapping dilakukan bersama masyarakat, dalam hal ini masyarakat. Langkah awal Tim memberi arahan kepada masyarakat untuk mencoba menggambar peta wilayah, beberapa pemuda kemudian membuat gambar wilayah yang kemudian di bantu oleh teman-temannya dalam menyempurnakan peta wilayah tersebut. 
Langkah selanjutnya yang dilakukan oleh tim adalah observasi lingkungan bersama masyarakat. Langkah ini sepenuhnya tidak dapat tim lakukan dengan masyarakat mengingat keterbatasan waktu dan padatnya rutinitas masyarakat yang kesehariannya bekerja sebagai petani, mereka mulai bekerja dari pagi hari, hingga sore hari. Tim kemudian dibantu oleh beberapa pemuda untuk melihat kondisi masyarakat, tim mencoba meneluri beberapa kawasan.

Di Dusun Merak, PLN belum masuk. Menurut penduduk, sekitar empat tahun yang lalu, baru ada mesin disel untuk penerangan pada malam hari. Pemakaian mesin desel itu pun masih amat terbatas tidak seluruh penduduk Dusun Merak dapat menikmatinya. Barangkali karena jarak antarrumah penduduk banyak yang berjauhan.

Penerangan memakai mesin disel itu juga amat terbatas waktunya; yaitu mulai pukul 17.30 sampai pukul 22.00 WIB. Setelah itu keadaan Dusun Merak ini benar-benar sunyi senyap dan tidak ada penerangan lampu. Kalau pun ada lampu, itu hanya beberapa rumah saja dari lampu berbahan minyak tanah. Sedang minyak tanah sekarang amat mahal dan langka. Karena harga minyak yang mahal ini, mereka tidak memakai kompor. Selama ini masyarakat kalau memasak memakai bahan kayu bakar. Kayu ini berasal dari pekarangan rumah atau tanah petegalannya.

Masyarakat Dusun Merak mayoritas hidup sebagai petani. Walaupun di Dusun Merak juga berbatasan dengan Laut Jawa, namun masyarakat lebih memilih hidup sebagai petani. Mereka menanam tanaman palawija di daerah petagalan. Dalam masalah pertanian ini, masyarakat mengeluhkan harga pupuk yang amat mahal dan sangat langka. Karena itu, masyarakat menginginkan agar di daerahnya terdapat pupuk organik.

Di Dusun Merak terdapat potensi lokal yang belum dimanfaatkan, yaitu kotoran sapi milik penduduk.di Dusun Merak terdapat sekitar 667 sapi milik penduduk. Sapi-sapi tersebut ada yang memang milik masyarakat Merak namun banyak pula yang milik penduduk luar Dusun Merak yang “dikelola” masyarakat Merak (sistem “paroh”).

Ratusan sapi tersebut kalau paginya dilepas begitu saja di tanah lapang pinggir Hutan Baluran. Menjelang senja, digiring ke pinggir pantai dikumpulkan dalam beberapa "kandang" yang berjejeran di tepi pantai. "Kandang" tersebut terbuka, tidak ada atap. Setiap penduduk yang memiliki sapi secara bergilir menjaga sapi tersebut di malam hari. 
Potensi sapi-sapi tersebut --misalnya kotorannya-- belum dimanfaatkan masyarakat Merak. Kalau nanti program biogas ini terlaksana maka akan menjadi milik masyakarat karena sapi-sapi tersebut memang milik masyarakat.Ratusan sapi itu, kalau pagi hari dilepas di hutan. Menjelang senja, digiring dan dikumpulkan ke sebuah tempat terbuka dekat rumah penduduk. Penduduk bergiliran menjaga sapi itu sampai pagi. Kotoran sapinya, sampai sekarang belum dimanfaatkan. Karena itu, kami berencana membantu mereka dengan membuat biogas. Dan ampas biogas digunakan sebagai pupuk organik yang akan membantu masyarakat dalam bidang pertanian.

\section{Menyusun Rencana Aksi Partisipatif}

Pada tahapan ini timmerancang kegiatan sesuai dengan problem yang ditemukan dari hasil kajian wilayah bersama-sama dengan warga yang didasarkan atas kebutuhan mereka. Mekanisme ini diterapkan untuk mendorong pembelajaran bersama di antara anggota kelompok yang berkepentingan (multi-stakeholder) dalam program ini.Adapun teknik pelaksanaan langkah kedua ini adalah:

Pertemuan kelompok, sebagai mekanisme untuk merenung, membangun kelompok dan perencanaan bersama. Melalui forum ini, masing-masing pihak didorong untuk mengenali problem yang mereka hadapi dan difasilitasi untuk merumuskan sebuah formula solusi secara bersama-sama. Forum kelompok ini dilakukan dengan mengumpulkan masyarakat untuk mendiskusikan persoalan-persoalan penting kemudian mencari solusi untuk memecahkan masalah. Benchmarking; juga bagian dari mekanisme perenungan, membangun kelompok dan perencanaan bersama terhadap beberapa tantangan dan kendala yang ingin dipecahkan secara kolektif. Tentu saja dalam langkah sistem pembelajaran bersama, anggota tim peneliti memiliki kesempatan untuk berpartisipasi aktif dalam forum kegiatan.

Nah dari hasil FGD dengan masyarakat ini kami akhirnya memfokuskan pengabdian dalam program dakwah pemberdayaan ini dalam dua bidang. Pertama, dalam bidang dakwah advokasi. Tujuan program ini secara umum penguatan masyarakat untuk memperoleh kembali kuasa kelola (powver of management system), kuasa milik (power of ownership system), dan kuasa manfaat (power of unility system) yang hilang. Kedua, dakwah ekonomi; dalam bidang ini kami lebih menitikberatkan dakwah pemberdayaan ekonomi berwawasan lingkungan. Tujuan program ini 
untuk menyejahterakan masyarakat dan meningkatkan partisipasi masyarakat pada pemeliharaan lingkungan sekitarnya serta meningkatkan pola kemitraan dengan TN Baluran. Ketiga, bidang keagamaan yang bertujuan untuk memberikan pemahaman tentang fiqh lingkungan sehingga masyarakat memiliki kepedulian tentang lingkungan sekitarnya. Bentuk programnya berupa halaqah fiqh lingkungan (biah).

\section{Melaksanakan Aksi}

Dalam proses aksi ini kami melibatkan masyarakat untuk melaksanakan program pemberdayaan ini, adapun aksi pengabdian kami antara lain:

Pertama, pada bidang dakwah advokasi yang bertujuan mempereoleh kembali kuasa kelola (power of management system), kuasa milik (power of ownership system), dan kuasa manfaat (power of unility system) yang hilang. Adapun program kerja yang kami lakukan, antara lain:

1. Pertemuan dengan masyarakat dan stakeholder. Kami mengadakan urun rembuk dengan masyarakat. Tujuannya untuk mendorong terjadinya perubahan terhadap kondisi masyarakat Merak. Masyarakat mengharap, penguatan untuk memperoleh kembali kuasa kelola (power of management system), kuasa milik (power of ownership system), dan kuasa manfaat (power of unility system) berdasarkan nilai-nilai keagamaan yang dianutnya.

2. Identifikasi kasus dan strategi advokasi. Bentuknya, urun rembuk atau FGD. Tujuan pada tahapan ini yaitu untuk mengidentifikasi kasus dan menyusun strategi advokasi selama lima bulan mendatang. Temuan identifikasi, terdapat sebagian masyarakat yang mulai hampir jenuh terhadap permasalahan tanah, karena advokasi yang dilakukan bertahun-tahun belum sesuai dengan harapan mereka.

3. Pengorganisasian masyarakat dan penggalangan sekutu. Tujuan pengorganisasian i yaitu untuk memperkuat basis dan networking. Sedangkan tujuan penggalangan sekutu untuk melakukakan penyamaan persepsi tentang pentingnya pemberdayaan masyarakat dan memperkuat jaringan agar mendapat dukungan dari beberapa pihak

4. Tekanan dan lobi.

5. Penyelesaian konflik dengan MoU.

Kedua, dakwah ekonomi yang memfokuskan pada dakwah bilhal berbasis lingkungan, 
yaitu: pelatihan biogas dan pupuk organik. Pelatihan ini diadakan karena di Dusun Merak terdapat energi alternatif yang membantu dalam kehidupan masyarakat. Setelah kami diskusikan dengan masyarakat Dusun Merak energi alternatif yang memungkin di daerah tersebut adalah biogas yang berasal dari kotoran sapi. Ampas dari biogas tersebut nantinya akan dibuat pupuk. Sehingga program ini nantinya akan berguna bagi masyarakat.Biogas tidak merusak lingkungan karena CO2 yang dihasilkan langsung dapat diserap tanaman sehingga emisi yang dihasilkan di atmosfer sangat sedikit. Kalau hal ini diterapkan maka tidak akan mengganggu kawasan hutan Baluran. Dengan demikian, program pembuatan biogas ini dapat mengurangi pencemaran udara, tanah, air, dan biologis.

Pelatihan ini diadakan karena untuk sektor peternakan, di dalam kawasan Merak terdapat lebih dari 667 ekor ternak sapi. Hampir sebagian masyarakat tidak memiliki ternak sendiri melainkan menernakan ternak orang lain baik yang berada di dalam kawasan maupun masyarakat yang ada di luar kawasan. Blok dengan jumlah ternak gadohan terbanyak adalah Blok Widuri. Penggembalaan liar di dalam kawasan Taman Nasional Baluran telah memicu masyarakat di sekitarnya untuk memanfaatkan rumput sebagai pakan ternaknya. Walaupun telah menggembalakan ternaknya tiap hari ke hutan tetapi tetap saja mereka juga mengambil rumput untuk mencukupi pakannya selama di kandang, terutama untuk persediaan di musim kemarau.

Program yang lain yaitu FGD dan aksi pemiliharaan terumbu karang dan bakau. Tipe hutan ini terdapat di daerah pantai Utara dan Timur kawasan Baluran seperti di Bilik, Lempuyang, Mesigit, Tanjung Sedano dan Kelor. Pada daerah bakau yang masih baik (Kelor dan Bilik) flora yang umum dijumpai adalah Api-api (Avicenia spp.), Bogem (Sonneratia spp.) dan Bakau (Rhizophora spp.). Pada beberapa tempat dijumpai tegakan murni Tinggi (Ceriops tagal) dan Bakau (Rhizophora apiculata).

Beberapa daerah lain seperti di Utara Pandean, Mesigit, sebelah Barat Bilik terdapat hutan bakau yang telah rusak. Daerah ini menjadi lumpur yang dalam pada musim hujan, tetapi akan berubah menjadi keras dan kering dengan lapisan garam di permukaan pada musim kering. Sedikit sekali pohon yang tumbuh disini dan tidak dijumpai tumbuhan bawah. Beberapa species yang tumbuh antara lain adalah Api-api (Avicenia sp.) dan Truntun (Lumnitzera racemosa). Menurut hasil inventarisasi Penilaian potensi hutan bakau di Taman Nasional Baluran tahun 
1994 / 1995 di daerah sekitar Bama terdapat salah satu pohon bakau yang diduga terbesar di duniadengan keliling pohon $450 \mathrm{~cm}$.

Mangrove (bakau) merupakan komunitas vegetasi pantai tropika yang didominasi oleh beberapa spesies pohon bakau yang mampu tumbuh dan berkembang pada kawasan pasang surut pantai berlumpur. Komunitas ini pada umumnya tumbuh pada kawasan intertidal dan supertidal yang mendapat aliran air yang mencukupi, dan terlindung dari gelombang besar dan arus pasang surut yang kuat. Karena itu hutan mangrove banyak dijumpai di pantai-pantai teluk yang dangkal, estuaria, delta dan kawasan-kawasan pantai yang terlindung

Pohon-pohon mangrove adalah halofit, artinya bahwa mangrove ini tahan akan tanah yang mengandung garam dan genangan air laut. Ada juga mangrove tumbuh di tempat yang lebih tinggi, sehingga akan mengalami masa tanpa di genangan air laut yang agak panjang. Namun beberapa pohon mangrove dapat dijumpai di tepi sungai sekitar $100 \mathrm{~km}$ dari laut, walaupun dipermukaan air dimana pohon itu tumbuh adalah air tawar, tetapi pada dasar sungai terdapat seiris air.

Di samping bakau, kami juga memelihara terumbu karang. Terumbu karang yang mempunyai bentuk bercabang, pipih seperti kipas, ataupun menyerupai kelopak bunga sesungguhnya merupakan tempat hidup koloni hewan dan tumbuhan karang. Tipe terumbu karang yang ada di sepanjang pantai Taman Nasional Baluran adalah karang tepi, memiliki lebar yang beragam dan berada pada kisaran kedalaman 0,5 meter sampai 40 meter. Zonasi terumbu karang di perairan Taman Nasional Baluran diawali dari: Dataran terumbu karang, berada pada kedalaman 0,5 meter sampai 3 meter dan didominasi oleh karang yang ukurannya kecil.

Puncak terumbu karang, didominasi oleh jenis karang keras (hard coral). Lereng terumbu, di zona ini sangat berpotensi karena hampir semua jenis karang dan ikan hias yang ada di perairan Taman Nasional Baluran dapat dijumpai di bagian ini. Daerah tubir merupakan daerah yang sangat menarik untuk kegiatan wisata alam bahari karena dipenuhi oleh jenis karang lunak (soft coral) dan jenis ikan yang bergerak secara berkelompok, sehingga menjadi atraksi alam bawah air yang mempesona. Terumbu karang mempunyai fungsi fisik sebagai pelindung pantai dari pengikisan air laut (abrasi), fungsi ekologi bagi kelangsungan hidup berbagai jenis ikan dan biota laut lainnya, serta fungsi ekonomi khususnya bagi penduduk 
pantai (nelayan) dan dapat dikembangkan untuk dimanfaatkan sebagai objek wisata alam bahari.

Terumbu karang merupakan komunitas yang unik di antara komunitas laut lainnya dan mereka terbentuk seluruhnya dari aktivitas biologi. Pada dasarnya karang merupakan endapan massive kalsium karbonat (kapur) yang diproduksi oleh binatang karang dengan sedikit tambahan dari alga berkapur dan organism-organisme lain penghasil kalsium karbonat. Klasifikasi ilmiah menunjukkan bahwa karang ini termasuk kelompok binatang dan bukan sebagai kelompok tumbuhan. Binatang karang ini masuk ke dalam phylum Cnidaria, kelas Anthozoa, ordo Scleractinia.

Pengelolaan terumbu karang berbasis-masyarakat adalah pengelolaan secara kolaboratif antara masyarakat, pemerintah setempat, Lembaga Swadaya Masyarakat, dan pihakpihak terkait yang ada dalam masyarakat yang bekerja sama dalam mengelola kawasan terumbu karang yang sudah ditetapkan/disepakati bersama. Tujuan dari pengelolaan terumbu karang berbasis-masyarakat adalah untuk menjaga dan melindungi kawasan ekosistem atau habitat terumbu karang supaya keanekaragaman hayati dari kawasan ekosistem atau habitat tersebut dapat dijaga dan dipelihara kelestariannya dari kegiatan-kegiatan pengambilan atau perusakan.

Tahapan aksi pemberdayaan masyarakat yang ketiga, yaitu aksi dalam bidang keagamaan. Kami memilih bidang ini karena untuk mempererat hubungan dengan masyarakat setempat. Karena masyarakat Merak sangat agamis, sehingga program yang dilaksanakan berbasis keagamaan akan mudah diterima oleh masyarakat Merak. Kami mengadakan halaaqah fiqh lingkungan. Kami memaparkan materi tentang usaha mewujudkan lingkungan bersih dan sehat perspektif Islam.

Dalam Bahasa Arab, lingkungan disebut dengan istilah “al-bî'ab”, merujuk kepada lingkungan fisik manusia di permukiman. Istilah lingkungan alam mencakup permukaan lahan, permukaan air, flora dan fauna yang tinggal di dalamnya, lapisan tanah yang menutupi permukaannya dan atmosfir yang terdapat di atasnya. Kesehatan lingkungan sangat dipengaruhi oleh kebersihan udara dan air.

Upaya mewujudkan kebersihan sesuai standar kesehatan dan kesucian menurut kriteria syariat perlu didukung oleh keseimbangan ekologis dan jaminan ketersediaan sumber daya alam. Salah satunya dilakukan melalui jalan konservasi sumber daya alam untuk menjaga 
kelestarian dan pemanfaatannya secara berkelanjutan.

\section{Refleksi dan evaluasi}

Setelah selesai melaksanakan aksi, kami mengadakan evaluasi dan refleksi bersama masyarakat Merak. Hasil pertemuan tersebut, antara lain:

Pertama, dalam bidang dakwah advokasi. yang bertujuan mempereoleh kembali kuasa kelola (power of management system), kuasa milik (power of ownership system), dan kuasa manfaat (power of unility system) yang hilang. Pada tahapan pengabdian ini kami merumuskan tentang pola kemitraan.

Kedua, dalam bidang dakwah ekonomi. Dalam bidang ini kami lebih menitikberatkan dakwah pemberdayaan ekonomi berwawasan lingkungan. Tujuan program ini untuk menyejahterakan masyarakat dan meningkatkan partisipasi masyarakat pada pemeliharaan lingkungan sekitarnya. Di samping itu, untuk mengembangkan pola kemitraan dengan TN Baluran sehingga mengurangi konflik. Program ini antara lain, pelatihan pupuk organik dan biogas.

Dari program ini ini terdapat beberapa kesepakatan antara lain: pertama, daya biogas terbatas, hanya 1000 watt. Keterbatasan ini karena dananya juga terbatas. Karena itu masyarakat sepakat, kalau program biogas yang kami rintis nantinya berhasil, masyarakat sendiri yang akan menindaklanjuti dan mengembangkan program biogas tersebut. Untuk pertama kali memang hanya lima rumah namun untuk seterusnya, satu RT, kemudian satu RW, dan berlanjutkan sehingga satu kampung. Sebab dari potensi kotoran sapi masih sangat memungkinkan. Karena sekarang, jumlah keseluruhan ternak sapi di Dusun Merak sekitar 667 pasang.

Kedua, ampas dari biogas tersebut akan dikembangkan menjadi pupuk organik. Pupuk organik tersebut untuk tanaman penduduk Merak dan sisanya akan ditampung di koperasi untuk dijual. Kalau biogas tersebut nantinya dikembangkan oleh masyarakat Merak, tentu pupuk organik semakin banyak dan daya tampung di koperasi juga semakin besar.

Ketiga, untuk ke depan juga akan dikembangkan energi alternatif lain yaitu listrik tenaga surya. Karena potensi Dusun Merak sangat memungkinkan untuk dikembangkan energi tenaga surya tersebut.

Program dalam bidang dakwah advokasi yang terkait dengan dakwah bilhal yaitu 
pemeliharaan hutan bakau dan terumbu karang. Program ini untuk meningkatkan kepedulian masyarakat kepada lingkungan sekitarnya. Sehingga masyarakat merasa memiliki lingkungan yang asri.

Program ke depan, kami sepakat untuk tetap berlanjut. Masyarakat mau mengembangkan dan menjalin kerjasama dengan TN Baluran yang mengembangkan ekowisata. Masyarakat menginginkan untuk berpartisipasi dalam hal "home stay". Sehingga para wiswan langsung dapat berinteraksi dengan masyarakat dan bertempat tinggal atau menginap di tengahtengah masyarakat.

Dalam halaqah fiqh biah, masyarakat memandang penting untuk menambah keilmuan dan wawasan keberagamaan yang terkait dengan lingkungan.

\section{Dampak Perubahan dan Hasil Pengabdian}

Adapun dampak perubahan dari hasil pengabdian tersebut, antara lain: Pertama, masyarakat yang sebelumnya menggunakan penerangan diesel dan lampu teplok (dari bahan minyak tanah) sekarang menggunakan biogas dari kotoran sapi. Sedangkan harga bahan bakar diesel yaitu solar dan minyak tanah harganya cukup mahal. Lagi pula, untuk daerah Merak kedua bahan bakar tersebut tidak ada, harus membeli di luar daerah. Dengan demikian program tersebut amat membantu masyarakat untuk lebih menghemat biaya yang dikeluarkan dalam belanja rumah tangga.

Kedua, masyarakat sekarang kalau memasak menggunakan biogas, sebelumnya, sebagian mereka menggunakan kompor minyak tanah atau mencari kayu sebagai bahan bakar di hutan. Dengan adanya program biogas tersebut kehidupan masyarakat semakin hemat dan praktis.

Ketiga, ampas hasil dari biogas untuk pupuk organik. Sebelumnya, masyarakat membeli pupuk untuk tanaman mereka. Pupuk tersebut sangat mahal. Dengan demikian masyarakat sangat terbantu dari sisi ekonomi. Untuk kedepan, pupuk organik tersebut juga akan dijual. Sehingga dapat menambah pendapatan masyarakat.

Keempat, program biogas ini juga ramah lingkungan. Karena biogas tidak merusak lingkungan karena CO2 yang dihasilkan langsung dapat diserap tanaman sehingga emisi yang dihasilkan di atmosfer sangat sedikit. Dengan demkian program pengabdian iniikut menjaga 
kawasan hutan Baluran. Program pembuatan biogas ini juga dapat mengurangi pencemaran udara, tanah, air, dan biologis.

\section{KESIMPULAN}

Fokus pengabdian dalam program ini adalah dakwah pemberdayaan masyarakat berwawasan lingkungan yaitu kegiatan dakwah pemberdayaan masyarakat. Terdapat tiga bidang garapan yang menjadi fokus pengabdian kami, antara lain:

Pertama, dalam bidang dakwah advokasi yang bertujuan mempereoleh kembali kuasa kelola (power of management system), kuasa milik (power of ownership system), dan kuasa manfaat (power of unility system) yang hilang. Pada bidang ini, kami merumuskan tentang pola kemitraan.

Kedua, dakwah ekonomi. Dalam bidang ini kami lebih menitikberatkan dakwah pemberdayaan ekonomi berwawasan lingkungan. Tujuan program ini untuk menyejahterakan masyarakat dan meningkatkan partisipasi masyarakat pada pemeliharaan lingkungan sekitarnya. Di samping itu, untuk mengembangkan pola kemitraan dengan TN Baluran sehingga mengurangi konflik. Program ini antara lain, pelatihan pupuk organik dan biogas. Program bidang ini juga berupa dakwah bilhal yaitu FGD dan aksi tentang pemeliharaan terumbu karang dan bakau.

Ketiga, bidang keagamaan yang bertujuan untuk memberikan pemahaman tentang fiqh lingkungan sehingga masyarakat memiliki kepedulian tentang lingkungan sekitarnya. Kegiatan ini berupa fiqh lingkungan (biah).

\section{REFERENSI}

A. Halim.2005. Paradigma Dakwah Pengembangan Masyarakat, dalam Dakwah Pemberdayaan Masyarakat Paradigma Aksi Metodologi, Yogyakarta, LKiS, 2005.

Adnan, H, dkk. 2015. Meretas Jalan Kemitraan. Jakarta: Kemitraan

Adnan, H, dkk, 2015b. Pemberdayaan Masyarakat Melalui Kemitraan Masyarakat (Panduan). Jakarta: Kemitraan

Al-Thabari, Tafsir al-Thabari, Maktabah al-Syamilah, juz I

Anshari, GZ. 2006. Dapatkah Pengelolaan Kolabortif Menyelematkan Taman Nasional Sentarum? Jakarta: Center for International Forestry Research

Fretas, JMDC, 2014. Kemitraan Pemerintah dan Masyarakat Lokal dalam Pengelolaan Hutan 
Mangrove di Pantai Utara Kota Surabaya. Jurnal JKMP. Vol.2 No. 2. September 2014, hlm.147-164

Ibrāhīm Ahmad Mahmūd Al-Harīrīy,1998. Al-Madbkal Ila Al-Qawāid Al-Fiqhiyyah (Dār 'Imar, Yaman

Imam Ghazali Said (ed), 2005. Abkamul Fuqaha, Solusi Problematika Aktual Hukum islam, Surabaya, Diantama-LTN NU.

Khamami Zada, Dakwah Transformatif: Mengantar Dai sebagai Pendamping Masyarakat, www.nu.or.id

M. Quraish Shihab, 2012. Tafsir al-Misbah, Lentera Hati, Jakarta

Mansour Fakih, 2006. Analisis Gender dan Transformasi Sosial. Yogyakarta, Pustaka Pelajar

Mas'udi, 1994. Teologi Tanah. Jakarta : CV Guna Aksara.

Misrawi, 2007. Al-Qur'an Kitab Toleransi [Iknlusivisme, Pluralisme, dan Multikulturalisme] Jakarta Selatan : Fitra

Nursyam, 2005, Pengembangan Komunitas Pesantren dalam Moh Ali Aziz (ed), Dakwah Pemberdayaan Masyarakat Paradigma Aksi Metodologi, Yogyakarta, LKiS.

Putra, AS. 2013. Pola Kemitraan Pariwisata dalam Manajemen Atraksi Desa Wisata Pampang Kota Samarinda. Jurnal Nasional Pariwisata. Vol.5.No.3, Desember 2013, hlm. 189-200

Rr. Suhartini, 2005. Pemberdayaan Perempuan, dalam Dakwah Pemberdayaan Masyarakat Paradigma Aksi Metodologi, Yogyakarta, LKiS.

Sayid Sābiq, Fiqh al-Sunnah

Sukidi, Pemberdayaan Perempuan Berbasis Pesantren, www.islamlib.com

Tadjuddin, Dj. 2000. Manajemen Kolaborasi. Bogor: Pusraka Latin.

Wahbah al-Zuhailīy, Al-Figh Al-Islämìy. 